E, no caso concreto do Brasil, o predomínio indiscriminado dos interesses das empresas transnacionais, na ordenação das atividades econômicas, conduzirá a tensōes inter-regionais em nivel explosivo, a rivalidades corporativas, a bolsōes de miséria. Em suma, à invibialização do país como projeto nacional.

Daí a sua angústia em saber "se temos um futuro como nação que conta na construçäo do devenir humano. Ou se prevalecerão as forças que se empenham em interromper o nosso processo histórico de formação de um Estado-nação" (página 35).

Fazendo frente à lógica perversa das forças dominantes, Celso Furtado coloca como imperativo a articulaçã̃o de uma estratégia de resistência que, no Brasil, iria da ativação do po- tencial produtivo interno e da integração dos mercados regionais à formação de uma vontade politica coletiva e transtormadora.

Resta saber: quais serão os agentes efetivos deste processo de resgate nacional? Até onde pode-se pensar num projeto de desenvolvimento autônomo, nesta quadra do século, que leve em consideração as efetivas necessidades das maiorias e que, mesmo não estando simplesmente sob a égide das forças de mercado, subordina-se à lógica do capital?

Passageiro da Utopia, Quixote, lúcido (como ele mesmo se vê), Celso Furtado não responde a estas questões, mas alerta que "como a História ainda não terminou, ninguém pode estar seguro de quem será o último a rir ou a chorar" (página 9).

\title{
THE GOOD SOLDIER: A TALE OF PASSION
}

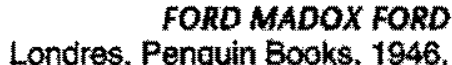

Por Roberto Venosa, Engenheiro, Mestre em Administração Pública pela Universidade de Pittsburgh, Doutor em Sociologia pela EHESS, Paris, Professor Titular do Departamento de Administraçăo Geral e Recursos Humanos da EAESP/FGV e Professor Visitante da University of St. Andrews, Escocia.

C ambridge reinicia seu ano letivo. Lembra um pouco algumas cenas do filme "A Sociedade dos Poetas Mortos". Pais orgulhosos carregam os apetrechos de seus filhos para os diversos colleges. E muito bonito poder ver e sentir a dose de emoção que cada novo aluno traz junto com sua bagagem. Enquanto me dirigia para a Faculdade de Ciências Sociais e Politicas, observando este lufalufa, reparei que dois carros estacionados em frente ao Clare College tinham chapas de diferentes países. Um era francês e o outro era inglês. No francês havia um adesivo escrito em francês que dizia o seguinte: Se wocê bater no meu carro eu amasso a sua cara! No carro inglês estava escrito no para-choque: Nos provavelmente nos encontraremos por acidente.

E exatamente esta pretensa descontração do inglês que Ford derruba, página apos página. $\mathrm{O}$ estilo de Ford tem um quể de preguiçoso e bastante lento, porém corta como bisturi. Seria muito querer compará-lo a um Proust. Certamente não o é. Mas, através da lentidão com que conta a saga de Edward Ashburnham, vamos penetrando a alma britânica. $\mathrm{O}$ que mais impressiona é a lucidez de Ford. Neste ponto, chega muito proximo do proustiano mergulho na alma humana. Ao longo da narrativa, $O$ autor mostra que a saída está aí; mesmo assím, as personagens optam pelo convencional. Sob este aspecto, lembra um pouco Foster, principalmente o Foster de $A$ room with a view pessimamente traduzido como: Uma janela para o amor. Ford năo é o que de mais recente se publicou no Reino Unido porém, para se entender organizações brasileiras, pode-se dispensar a leitura de um Machado de Assis?

Em alguns cursos que conduzi na EAESP/FGV introduzi a leitura de romances. Existe melhor aula de sucessão em pequenas empresas que Os Buddenbrook de Thomas Mann? O Mundo se despedaça do nigeriano Chinua Achebe não pode ser lido como um dos melhores ensaios sobre processo de modernizaçäo? E o olhar antropológico de Yvonne Maggie em Guerra de Orixá não é uma exce- 
lente metáfora da luta pelo poder nas organizaçôes? The Good Soldier é uma maravilhosa análise da solidão nas classes altas. Lido em inglês, requer um bom domínio da língua. Ford näo faz concessöes. Mas, ainda que se tenha que ler com o dicionário do lado, é uma aula magna sobre o comportamento humano. Imperdivel para um bom administrador que queira compreender o profundamente humano.
Ford é um pescador de almas. Como termina Ford: "Foi uma história muito interessante: poderia ter sido ainda mais interessante se eles tivessem cavado seus olhos com facas pontiagudas; mas eles eram 'such a good people". Ford pode nấo ter produzido uma obra proustiana, mas certamente oleitor que se delicia com a leitura de Machado, lerá com prazer The Good Soldier. Afinal, gerir organizações não nos obriga a entender as razöes humanas? 'J

\section{TRABALHO \& SOCIEDADE: PROBLEMAS ESTRUTURAIS E PERSPECTIVAS PARA O FUTURO DA "SOCIEDADE DO TRABALHO"}

\section{Traduzido por Gustavo Bayer E. Margrit Martincic. Rio de Janeiro Tempo Brasileino OFFE 180 páginas, vol. 2 (Bibtioteca Tempo Universitário n 89 , Série Estudos Alemäes).}

Por Tarclla Luzia da SIlva, Doutoranda em Administraçăo pela EAESPIFGV a Professora da Universidade Federal do Mato Grosso do Sul.

- Por José Carlos Barblerl, Professor do Departamento de Administração de Produção e Operações Industriais da EAESP/FGV e Professor na Área de Administração e Economia na Universidade Federal do Mato Grosso do Sul (UFMS/CCHS).

D esde a década de 40 está presente nas Ciências Sociais a hipótese de que a partir de um certo grau de industrialização, a tendência de desenvolvimento da "Sociedade industrial" se alteraria no sentido de expansão do setor "terciário". Os indicadores usados para verificar e confirmar essa hipótese são, principalmente, o peso do setor de serviços no produto interno e a participação da força de trabalho do setor de serviços na populaçăo economicamente ativa. São exemplos: os trabalhos de Clark (1940), Stigler (1956) e Fuchs (1968), que contribuíram de modo significativo para o reconhecimento $\mathrm{da}$ importância do setor de serviços nas sociedades modernas. Para esse último autor a economia norte-americana havia se transformado na primeira economia de serviços do mundo, ou seja, havia passado de uma economia industrial para uma outra onde a maioria de sua população economicamente ativa encontravase empregada nas atividades de serviços. Trabalhos como esses contribuíram para formar uma corrente de pensamento que entende ser o setor de serviços o setor determinante do dinamismo da economia como um todo, substituindo o papel que desempenhara o setor industrial.

Essa tendência gerou, principalmente entre cientistas sociais norte-americanos, interpretaçōes genéricas e abrangentes cunhando conceitos como: "sociedade administrada", "sociedade pós-industrial", ou ainda "sociedade dos serviços pessoais".

Claus Offe elaborou esse trabalho a partir da observação do uso genérico desses conceitos, verificando a necessidade de se questionar essa conceituaçăo que parte de definiçôes enumerativas para chegar a "não conceitos" do que seja serviços, ou seja, serviço definido como resíduo.

Na primeira parte do livro Crescimento e Racionalização do Setor de Serviços, Offe dedica-se a analisar o comportamento desse setor através de uma classificação desconhecida na ampla literatura sobre o tema e, partindo dessa 